\title{
Radiodermatitis - review of treatment options
}

\author{
Bojana SPASIĆ ${ }^{*}$, Marina JOVANOVIĆ1,2, Zoran GOLUŠIN ${ }^{1,2 * *}$, Olivera IVANOV²,3, \\ Dušanka TEŠANOVIĆ ${ }^{2,3}$ \\ ${ }^{1}$ Clinic of Dermatovenereology, Clinical Center of Vojvodina, Novi Sad \\ ${ }^{2}$ Faculty of Medicine Novi Sad, University of Novi Sad \\ ${ }^{3}$ Institute for Oncology of Vojvodina, Sremska Kamenica \\ *Correspondence: Bojana Spasić, E-mail: k2diagnostic@gmail.com \\ ${ }^{* *}$ Correspondence: Zoran Golušin, E-mail: zoran.golusin@mf.uns.ac.rs \\ UDC 615.849.06:616.5-002]-08
}

\begin{abstract}
Radiation dermatitis is one of the commonest side effects of ionizing radiation which is applied in radiotherapy of carcinoma of all localizations, most frequently of tumors of breast, head and neck region, lungs and soft tissue sarcomas. It usually occurs as a complication of breast radiotherapy and thus it is more often recorded in female patients on the skin in the region of breast subjected to radiation. Clinical manifestations of radiation dermatitis can be divided into four phases: acute phase (erythema, dry desquamation, moist desquamation, ulceration and necrosis with resulting re-epithelialization, residual post-inflammatory hyperpigmentation, reduction and suppression of sebaceous and sweat glands and epilation); subacute phase (hyperpigmentation and hypopigmentation, telangiectasia, skin atrophy, even ulceration); chronic phase (skin atrophy, dermal fibrosis and permanent skin epilation) and late phase (increased risk of skin cancer). In order to prevent radiation dermatitis, skin care products should be applied throughout radiotherapy that will decrease the frequency of skin reactions or block them and thus improve life quality. Although the therapy includes not only topical corticosteroids but numerous other products with active ingredients such as aloe vera, calendula, hyaluronic acid, sucralfat, sorbolene, mineral and olive oil, honey, vitamin C, zinc, antimicrobials and silver, common therapeutic consensus has not been reached on their application in radiation dermatitis. Therefore, the treatment should be conducted according to the basic guidelines but tailor-made for each individual patient.
\end{abstract}

Key words: Radiodermatitis; Signs and Symptoms; Radiation Injuries; Radiation Protection; Skin Care; Deodorants; Skin Cream; Anti-Infective Agents

\section{Introduction}

Radiotherapy is a mode of treating tumor by using ionizing radiation, i.e. high energy radiation of affected tissue. Any radiation that is in interaction with a substance through which it penetrates either directly or indirectly and performs ionization of its atoms and molecule is ionizing radiation. Ionizing radiation has both direct and indirect effects on a living matter. It is implemented by high energy $x$ and gamma photons, electrons, heavy ions (carbon ion), Pi mesons, protons and neutrons. A standard-fractionated radiotherapy is implemented in doses of 40 to 50 Gy, 5 days a week for 5 to 6 weeks. Radiotherapy should be started 6 to 8 weeks after the completion of the previous mode of treatment. About $95 \%$ of patients undergoing radiother- apy experience some of its complications, which are a major therapeutic problem and interfere with life quality of patients $(1,2)$. Radiotherapy side effects can be divided into early or acute complications, which occur during the first six months from the beginning of radiation and they are usually reversible, and late complications, which occur from 6 months to several years and they are often irreversible. Complications are directly proportional to the applied dose, type of radiation and regimen of exposure, but they also depend on other factors as well $(3,4)$.

Radiation dermatitis is one of the commonest side effects of ionizing radiation which is applied in radiotherapy of carcinoma of all localizations, most frequently of tumors of breast, head and neck region, lungs and soft 
tissue sarcomas $(1,5,6)$. The incidence and severity of RD depend on several factors, characteristics of patients, mode and duration of treatment. The incidence of severe RD can be significantly decreased by applying megavoltage radiation and conformal radiotherapy.

Radiation dermatitis results from a high dosage of ionizing radiation of the skin during radiotherapy treatment of the above-mentioned tumors.

Radiation dermatitis most frequently occurs as a complication of breast radiotherapy and it is therefore most commonly found in female patients on the skin of breast subjected to radiation (2).

\section{Factors Effecting Skin Damage Degree}

The degree of skin damage depends on two main groups of factors: physical properties of the applied radiation on one side and the characteristics of the patients undergoing radiotherapy on the other.

Type and dose of ionizing radiation: megavoltage high energy linear accelerators enable the delivery of the maximum radiation dose under the skin surface, thus the skin can be protected better when such types of radiation are applied. Orthovoltage and kilovoltage linear accelerators produce ionizing radiation of lower penetrability, thus the doses on the skin are higher and therefore more severe damage can be expected with the in-

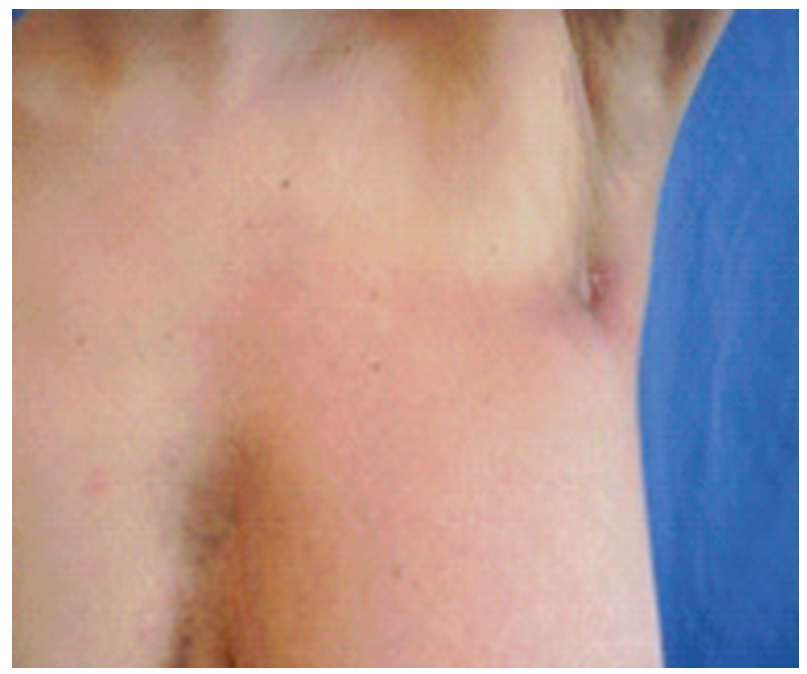

Figure 1. Female patient: Skin erythema, visible at $10^{\text {th }}$ fraction of planned RT (2Gy per fraction). creased dose of ionizing radiation and due to longer exposure to ionizing radiation (higher number of fractions) or higher individual dose in one fraction (7).

Size of radiation field and site of irradiation: the larger the field of exposure to ionizing radiation the higher is the possibility of damaging the skin, particularly in the regions of irregular surface (folds, joints, point of contact of two surfaces), where it is impossible to achieve a homogenous distribution of the dose but "hot spots" occur (7).

Fractionation regimen: radiation therapy can be implemented by the standard fractionation (daily dose on every working day at a dose of 1.8-2 Gy) or as hypofractionated radiotherapy (daily doses over 2Gy) or in several daily fractions (hyperfractionated radiotherapy). Hypofractionated regimens are particularly recommended when toxic effects of ionizing radiation are expected because a dose less than 1.8Gy per a fraction is then given and healthy cells can repair themselves in the period between two fractions (7-9).

Skin integrity damaged before the beginning of radiation: due to previous radiotherapy of the same region, connective tissue disease, eczema, psoriasis, colagenoses, postoperative scar (10).

Skin type: Individuals having Fitzpatrick skin type I and II are more prone to radiation damage (11). They have fair complexion, fair hair and blue or green eyes. Fitzpatrick scale

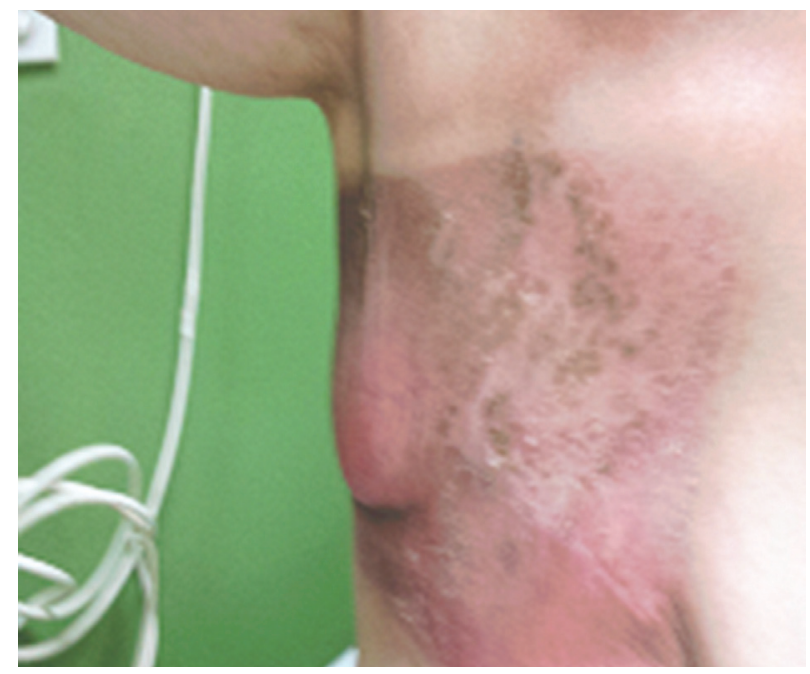

Figure 2. Female patient: Dry desquamation at $20^{\text {th }}$ fraction of planned RT 
includes six types of skin and it determines the skin reaction to UV radiation. The scale is constantly developed to predict the skin reaction to trauma and some dermatological procedures - lasers and dermato-surgery, i.e. its ability to tan.

Smoking: due to the damaged tissue oxygenation and increased level of carboxyhemoglobin $(2,12,13)$.

Nutritional status: due to the damaged mechanism of skin reparation (2)

Age: children are more sensitive

Comorbidities: (chronic renal insufficiency, diabetes, obesity, hormone disorders): due to disturbed metabolism and accumulation of toxic substances (urea, creatinine, uric acid, glucose) as well as disturbed distribution of water in the organism.

\section{Clinical Picture}

Radiation dermatitis has its phases in changes successively taking place in the skin. Thus, the clinical picture of RD can be divided into four phase (3):

Acute phase happening at the beginning of radiation up to 6 months after the exposure to radiation. The following side effects are the most frequent consequences of skin irradiation: erythema, dry desquamation, moist desquamation, ulceration and necrosis with the consequent re-epithelialization, residual post-inflammatory hyperpigmentation, reduction and suppression of sebaceous and sweat glands and epilation.

Erythema is the earliest change happening during even the first week of radiation at the dose of 2Gy. Real erythema develops within 3-4 weeks as a consequence of obliteration of arterioles. Clinically, the skin is erythematous, edematous, and warm and the subjective feeling is that the skin is tight and painful.

Dry desquamation most frequently develops as a result of reduction in the germinative layer of epidermis in the second week of radiation therapy. Destroyed cells are replaced by division of survived cells in the epidermis within 2-4 weeks. One of the clinical manifestations is skin desquamation and itching.

Moist desquamation results from further increase in doses or in case of excessive doses with the already present complications from the early phase such as erythema and dry desquamation. Moist desquamation develops as a consequence of the damaged basal layer, damaged vascular elements resulting in the denuded dermis so that the fluid is diffused from the dermal capillaries onto the surface.

Ulceration and necrosis rarely develop, and if they do, they result from re-irradiation usually 6 weeks or 2 months after radiation if vascular elements and connective tissue are damaged or if an infection has developed.

Re-epithelialization develops within 6 to 8 weeks by merging of healthy cell islets. The tissue recovery is a result of stimulation of homeostatic mechanisms and it starts with the cell migration from the edges of radiation field and cell differentiation from the basal layer.

Skin pigmentation occurs most frequently 2 to 3 weeks after the beginning of radiation at doses of $12-20 \mathrm{~Gy}$, with the resulting production of melanin in melanocytes.

Reduction and suppression of sebaceous and eccrine glands are one of early complications of radiotherapy and result in skin dryness, fissures on the skin and increased possibility of developing infection and skin necrosis.

Epilation caused by radiation is a result of high sensitivity of anagen follicles to radiation. Loss of dystrophic hairs (anagen effluvium) caused by acute damage of active separation of matrix cell of anagen follicle is followed by telogenic withdrawal due to early transition of follicles into late anagen (14). 3Gy produces complete, reversible anagen alopecia; permanent alopecia begins at 5Gy (14). Complete regeneration of hair mostly begins 2 to 4 months after radiation in the reversible type of alopecia induced by radiation.

Evaluation of early skin reactions to radiotherapy can be done by a validated tool, and the most frequently used validated scale is the one created by the Radiotherapy Oncology Group (RTOG) (15) (Table 1):

Before radiotherapy is started, it is necessary to estimate the current condition of patients' skin and continue to follow up skin changes in the patients during radiotherapy at least once a week in order to prevent and reduce unwanted reactions of radiotherapy on the skin $(16,17)$. 


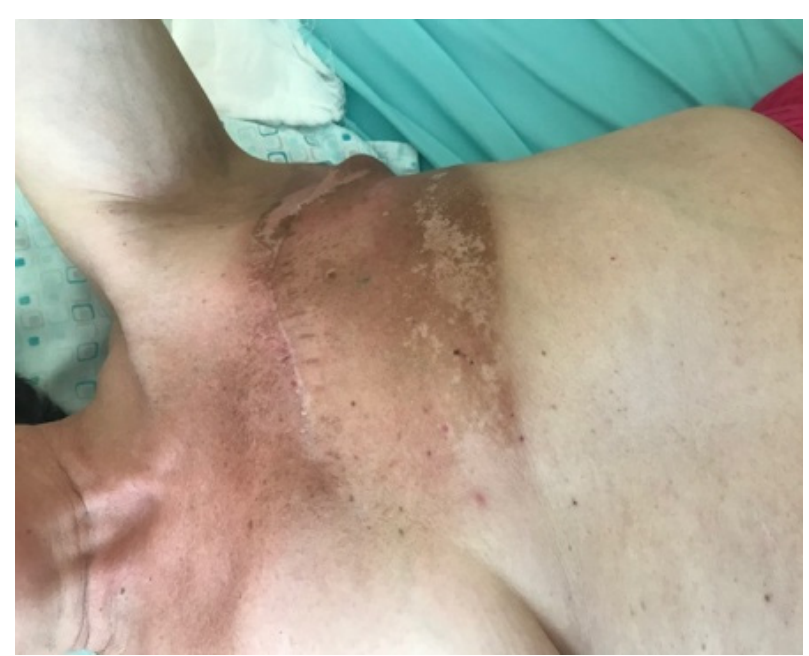

Figure 3. Female patient: Moist desquamation and hyperpigmetation of the skin after completed postoperative RT with TD 50Gy in 25 fraction

Subacute phase commences in the period from 6 months to a year after the completion of radiotherapy when hyperpigmentation and hypopigmentation, telangiectasia, skin atrophy occur and even ulcerations are possible on the spots of skin re-epithelialization.

Chronic phase commences in the period from a year to 5 years after the completion of radiotherapy. The most common manifestations are skin atrophy, dermal fibrosis (damaged fibroblast, increased production of collagen in dermis), telangiectasias (damaged blood vessels, ischemia and necrosis of small blood vessels) and permanent skin epilation.

Late phase begins 5 years after radiation. The radiated skin regions are at higher risk of developing skin cancer $(3,18)$.

Various pathogenetic mechanisms of development of secondary carcinoma after radiotherapy have been described (4). lonizing radiation leads to disruption of one of DNA chains, which can be converted into disruption of both DNA chains. Disruption of both DNA chains leads to mutation in genes, which results in malignant transformation of irradiated cell. Proteins synthesized during incorrect DNA reparation can also lead to the predisposition of development of malignant neoplasm. Cancerogenic potential of ionizing radiation is particularly increased when doses of and exceeding $45 \mathrm{G}$ are applied. Bystander effect implies development of secondary malignancies in a region away from the primary

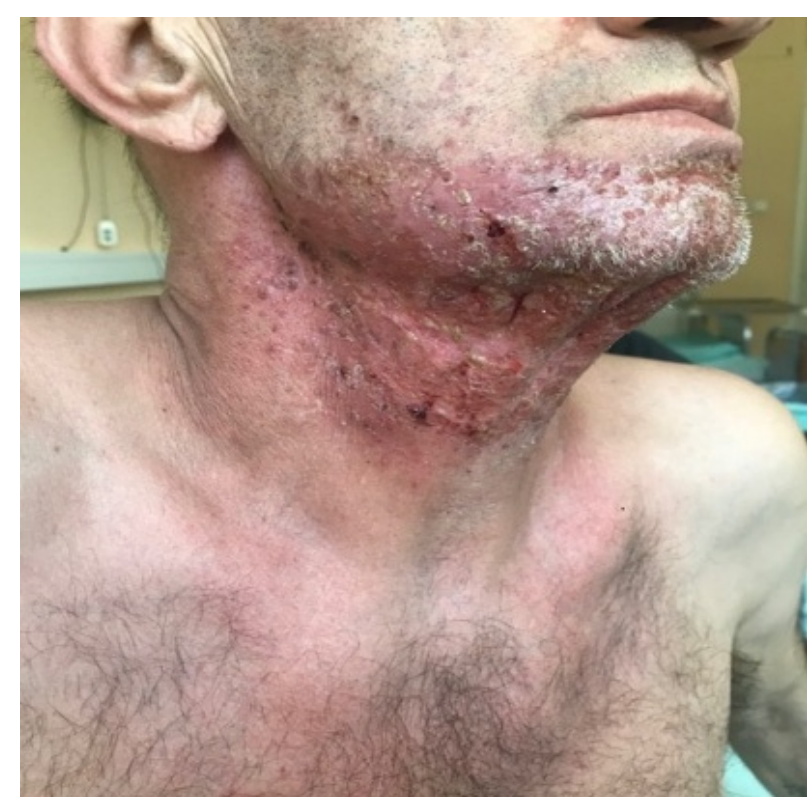

Figure 4. Male patient: Ulceration, moist desquamation and acneiform reaction as a complication of combined radiotherapy treatment (RT accompanied with Cetuximab)

tumor as a result of systemic effect of cytokines which are released during radiotherapy (19). After the initial dose of X-radiation, a certain percentage of DNA chain basal cells is damaged, and other cells receive a signal for mitosis in order to compensate for damage, they mature faster, which leads to a disorder in the balance between epidermopoiesis of basal cells and necrosis of cells with damaged DNA. When radiation treatment is continued, apoptosis of basal cells continues; inflammatory response with secretion of histamine and serotonin is stimulated as well as vascular response with capillary dilation and extracapillary damage of monocytes.

\section{Prevention of Radiation Dermatitis}

Before radiotherapy is started, the effect of various factors influencing the development of skin reactions during radiotherapy should be considered. These factors can be internal - age, diabetes, hormone status, obesity, smoking habit (patients should be advised about diet and to stop smoking) and external, which are associated only with radiation, adjuvant chemotherapy and target therapy (13, $20,21)$. An important aspect during radiother- 
Table 1. Evaluation of the intensity of early skin reactions induced by ionizing radiation, RTOG

\begin{tabular}{|c|c|c|c|c|}
\hline grade 0 & grade 1 & grade 2 & grade 3 & grade 4 \\
\hline \multirow{4}{*}{ no changes } & painless erythema & $\begin{array}{l}\text { intense, sensitive, } \\
\text { painful erythema }\end{array}$ & desquamation & ulcerations \\
\hline & epilation & desquamation & moist desquamation & hemorrhage \\
\hline & desquamation & moist desquamation & expressed edema & necrosis \\
\hline & dry skin & $\begin{array}{c}\text { moderately expressed } \\
\text { erythema }\end{array}$ & & \\
\hline
\end{tabular}

apy is the application of skin care products, which should reduce or prevent the frequency of skin reactions and improve life quality of patients undergoing radiotherapy $(22,23)$.

Recommendations regarding skin care in patients undergoing radiotherapy are different because of the insufficient number of clinical studies whose results would corroborate or reject the application of any topical preparation. Gosselini et al. believe that skin care should be directed to alleviation of symptoms (pain in the first place) and achievement of the feeling of comfort, i.e. maintenance of life quality of patients. It is important to include a psychologist in treatment of oncologic patient because it is known that patients prefer to undertake "an action" than do nothing (24). Recommendations given in more recent studies are contrary to traditional ones stating that the skin should not be washed and deodorants should not be used, which would affect life quality of patients in a way that they would worry about their body odor (25-29).
Nowadays it is recommended to wash the irradiated field with tepid water and mild $\mathrm{Ph}$ neutral or non-alkaline soap as a routine skin care procedure of patients during radiotherapy. It has been concluded that limitations in body washing and hair shampooing may affect social health of the patients (30-32).

According to the evaluations of skin condition done by RTOG assessors during and after radiotherapy, the patients who used water and soap to wash themselves were found to have reduced itching, erythema and desquamation at the end of treatment $(33,34)$. Aqueous cream can also be used instead of soap (British National Forum). After washing, the skin must be dried gently, a rough towel must not be used to avoid skin irritation (3537). The skin must not be warmed or cooled, exposed to wind. Rubbing should be avoided; razors should not be used for shaving nor should wax be used for hair removal $(24,38)$. Hair is to be washed with usual shampoo, but it should not be dried with a hair-dryer be-

Table 2. Therapy of Radiation Dermatitis

\section{Therapeutic options of radiation dermatitis}

- water and mild Ph neutral or non-alkaline soap

- aqueous cream

- deodorants

- non steroid topical therapy: lotions, creams, ointments, dressings, barrier films with active ingredients includ-

ing aloe vera, calendula, hyaluronic acid, sucralfate, sorbolene, mineral and olive oil, honey, vitamin $\mathrm{C}$, zinc,

- topical steroid therapy

- antimicrobials agents, including silver sulfadiazine

- hydrophilic dressings

- semipermeable dressings or hydrogels

- surgery

- sunscreens 
cause of irritation and drying of the skin if the head region is being irradiated $(35,39)$.

The patients are not allowed to use deodorants unless the skin is intact $(25-28,37)$. They are advised to wear comfortable clothes made from natural fibers, such as cotton Tshirts (24). They should apply sunscreens on the photoexposed skin (the skin must not be exposed to direct solar radiation) and wear wide brim hats (40).

In 2014 Chan et al. made a systematic review of literature including 47 randomized controlled trials within a meta-analysis aimed at determining the effect of systemic and local therapy (skin washing, use of deodorants, steroids, non-steroid local therapy and dressing) in treatment of RD in the period from 1962 to 2012. Six of these trials examined oral systemic therapy; 2 trials compared the condition of skin washed and not washed during radiation therapy; 4 trials dealt with the use of deodorants; 5 and 23 trials examined the application of topical steroid therapy and nonsteroid topical therapy, respectively and 6 trials examined dressings. Out of $47 \mathrm{RCT}, 36$ trials were assessed as having a high level of risk of bias, 10 trials had an undefined risk and one had a low risk of bias.

The absence of consensus regarding the issue of standard skin care of patients undergoing radiotherapy results from non-standardized methodology of choice, follow-up and evaluation of examined parameters (41). However, common consensus on guidelines may be reached in two fields: 1) aqueous cream as a substitution of soap, but it should not be used as an additional moisturizer, i.e. it cannot replace moisturizing creams (emollient creams); 2) deodorants - there is no proof based on the evaluation of toxicity, life quality and symptoms done by RTGO which would corroborate the practice of avoiding the application of deodorant 1 to 4 hours before radiotherapy (42). They are now commonly believed not to have a negative effect as it used to be thought before (27). Although the results of studies performed so far suggest that there was no difference between metallic and nonmetallic deodorants and that skin reactions occur as a consequence of irritating chemical ingredients of the product but not as a consequence of radiation, increased surface of radiation or bolus effect, the application of deodorants with aluminum must be further researched (28).

\section{Topical therapeutics}

In addition to corticosteroids a lot of products such as lotions, creams, ointments, dressings, barrier films with active ingredients including aloe vera, calendula, hyaluronic acid, sucralfate, sorbolene, mineral and olive oil, honey, vitamin C, zinc, antimicrobials and silver have been recommended; however, there is no common consensus on their use (Table 2).

Although the results of numerous studies suggest that aqueous cream applied to prevent development of erythema does not have any effects (24), the Society and College of Radiographers (SCoR) have published data which state that in $65 \%$ of departments performing radiotherapy aqueous cream is recommended and used to alleviate erythema, reduce the feeling of skin dryness, increase moisturizing of the skin and achieve higher satisfaction of patients (43). Aloe vera is also recommended to be used to alleviate erythema in $11 \%$ of departments performing radiotherapy but there is no consensus on its application either $(17,44,45)$. However, when higher cumulative doses of radiation therapy, exceeding 27Gy are given, administration of aloe vera gel has yielded some protective effects from unwanted reactions, which is due to its anti-inflammatory and anti-bacterial effect (46). Calendula officinalis cream has been categorized as a "probably efficient" cream by Oncology Nursing Society (ONS) according to the putting evidence into practice analysis $(47,48)$.

Hyaluronic acid is a polymer that stimulates fibroblasts and simultaneously neutralizes free oxygen radicals; in the form of $0.2 \%$ hyaluronic acid cream, it can accelerate the phase of granulation in radiation ulceration healing $(49,50)$. The results of studies done by Leonardi et al. and Primavera et al. have shown that there is a considerably reduced intensity and duration of unwanted reactions, erythema on the skin and subjective feeling in the patients who used hyaluronic acid as compared with the placebo group $(51,52)$.

Enhanced migration of keratinocytes into the wound region, faster replication of these cells and faster epithelialization were deter- 
mined by examining the influence of low molecular fraction of hemodialysate on wound healing after radiation therapy $(53,54)$.

According to SCoR data, hydrocortisone is used locally in $10 \%$ of departments performing radiotherapy to treat dry desquamation, that being in accordance with guidelines published by the College of Radiographer, 2000 and those of the Multinational Association for Skin Care of Patients treated with radiotherapy (27). Corticosteroids are often prescribed to prevent and treat RD due to their anti-inflammatory effects. However, the results of studies which compared the effects of prophylactic application of $0.2 \%$ hydrocortisone cream and placebo in management of post-irradiation reactions of skin are contradictory (55-61). The results of double blind randomized study on the prophylactic use of mometasone fuorate (MMF) or emollient cream in prevention of acute complications of radiotherapy on the skin of women with breast cancer have shown that the degree of erythema and pigmentation in the patients who had used emollient cream was considerably higher compared with the patients who had used MMF $(58,62)$.

Prophylactic use of sucralfate, which is a stimulator of cell growth in the form of cream, has not resulted in the expected reduction of intensity of erythemic radiation reactions in the skin, contrary to the anti-inflammatory effect exerted by sucralfate on experimental animals (63).

Barrier films are skin protectors that physically prevent the loss of skin moisture and reduce skin trauma and thus decrease skin damage caused by radiation. They have been proved efficient in treatment of moist desquamation of radiodermatitis $(44,64)$.

Antimicrobial agents, including silver sulfadiazine, should not be used for prophylaxis but only to treat infections, taking advantage of sulfadiazine ability to reach a high concentration locally on the skin with minimal systemic absorption (65).

\section{Hydrophilic dressings}

Hydrophilic dressings are dressings which could be partially permeable in the form of hydrocolloid or gel. Dressings mske wound re-epithelialization faster by promoting migration of epithelial cells. The most frequently cited study estimated the effect of moisture vapor permeable (MVP) dressing, i.e. dressings which permit evaporation and retain moisture in the treatment of $R D$ in the phase of moist and dry desquamation. The comparison of effects of MVP dressings and hydrophilic lanolin dressings has shown that MVP dressings are superior (66).

It is well known that silver dressings have good effects in treatment of venous ulcers, burns, chronic wounds with secondary bacterial infection. fVong et al. compared silver sulfadiazine cream with silver leaf nylon dressings. Their study has underlined the benefit of anti-bacterial dressings, which have been proved to have good therapeutic effects in the patients with neoplasm of the anal and genital region whose perineum skin has also been affected by radiotherapy. The dressings have considerably reduced development of grade 3 skin reactions whereas grade 4 skin reactions did not develop (67).

\section{Therapeutic Guidelines}

The patients are advised to use moisturizing, emollient creams, free of sodium lauryl sulphate to reduce skin irritation during radiotherapy $(68,69)$. These recommendations are also given for therapeutic and preventive reasons to the patients having RD grade 1 and 2 (according to RTOG scale), i.e. erythema, edema, and dry desquamation.

Administration of calendula cream and certain formulations of creams with hyaluronic acid is recommended to reduce the incidence of moist desquamation in grade 3 and barrier films are recommended for treatment.

If a bigger skin area is denuded in grade 3 , toilet of skin changes is necessary with hydrophilic, hydrocolloid, semipermeable dressings or hydrogels, which should be changed several times a day. Topical corticosteroids are also useful as well as silver dressings in prevention of bacterial infections.

In case of increased risk or justified suspicion of development of secondary bacterial infection, sulfadiazine cream can be applied until biogram and antibiogram are made. Topical antibiotics should be avoided unless the wound smear has been taken and bacterial infection proved $(70,71)$. 
If skin changes aggravate, ulcers are formed and bleeding and/or intense pains occur in grade 4, a surgeon must be consulted.

\section{Conclusion}

Skin reactions to radiation therapy can be severe, grave, disturbing and unpleasant; therefore, treatment and prevention of skin reactions must be approached seriously, and the pre-condition is to make the timely and accurate diagnosis. Treatment must be conducted according to the basic guidelines but tailor-made for each individual because of multifactor causes of development of radiation dermatitis (72).

\section{Abbreviatioins \\ $\mathrm{RD}$ - radiation dermatitis \\ RTOG - Radio Therapy Oncology Group \\ SCoR - Society and College of Radiogra- phers \\ ONS - Oncology Nursing Society \\ MMF - mometasone fuorate}

\section{References}

1. Bernier J, Bonner J, Vermorken JB, Bensadoun RJ, Dummer R, Giralt J, et al. Consensus guidelines for the management of radiation dermatitis and coexisting acne-like rash in patients receiving radiotherapy plus EGFR inhibitors for the treatment of squamous cell carcinoma of the head and neck. Ann Oncol. 2008;19(1):142-9.

2. Spalek M. Chronic radiation-induced dermatitis: challenges and solutions. Clin Cosmet Investig Dermatol. 2016;9:473-82.

3. Đurović B. Radijacione povrede kože. U: Karadaglić Đ, editor. Dermatologija. Beograd: Karadaglić Đ; 2016. p. 1486-500.

4. Kumar S. Second malignant neoplasms following radiotherapy. Int J Environ Res Public Health. 2012;9(12):4744-59.

5. Spasić $B$, Tešanović $D$, Ivanov O. Skin toxicity associated with Cetuximab treatment during radiotherapy of head and neck cancer. In: Abstracts of the 20th Congress of the Serbian Association of Dermatovenerologists; 2017 May 18-20; Belgrade, Serbia. Serbian Journal of Dermatology and Venereology. 2017;9(2):92.

6. Stojanović $S$, Jovanović $M$, Vučković N. Unusual growth of upper lip squamous cell carcinoma: a case report. Iran Crescent Med J. 2015;17(3):e13478.

7. Beyzadeoglu M, Ozyigit G, Ebruli C. Basic radiation oncology. 1st ed. Berlin; London: Springer; 2010.
8. Hansen EK, Roach M, editors. Handbook of evidencebased radiation oncology. 2nd ed. New York: Springer; 2010.

9. Malkinson FD, Panizzon RG. Radiobiology and radiotherapy of skin diseases. In: Freedberg IM, Eisen AZ, Wolff K, Austen KF, Goldsmith LA, Katz SI, editors. Fitzpatrick's dermatology in general medicine. 6th ed. New York: McGraw Hill; 2003. p. 1229-38.

10. Morgan K. Radiotherapy-induced skin reactions: prevention and cure. Br J Nurs. 2014;23(Suppl 16):S24-32.

11. Sachdeva S. Fitzpatrick skin typing: applications in dermatology. Indian J Dermatol Venereol Leprol. 2009;75(1):93-6.

12. Porock $D$. Factors influencing the severity of radiation skin and oral mucosal reactions: development of a conceptual framework. Eur J Cancer Care. 2002;11(1):33-43.

13. Sharp L, Johansson $H$, Hatschek T, Bergenmar M. Smoking as an independent risk factor for severe skin reactions due to adjuvant radiotherapy for breast cancer. Breast. 2013;22(5):634-8.

14. Severs GA, Griffin T, Werner-Wasik M. Cicatricial alopecia secondary to radiation therapy: case report and review of the literature. Cutis. 2008;81(2):147-53.

15. Trotti A, Byhardt R, Stetz J, Gwede C, Corn B, Fu K, et al. Common toxicity criteria: version 2.0. an improved reference for grading the acute effects of cancer treatment: impact on radiotherapy. Int $\mathrm{J}$ Radiat Oncol Biol Phys. 2010;47(1):13-47.

16. Fisher J, Scott C, Stevens R, Marconi B, Champion L, Freedman GM, et al. Randomized phase III study comparing Best Supportive Care to Biafine as a prophylactic agent for radiation-induced skin toxicity for women undergoing breast irradiation: Radiation Therapy Oncology Group (RTOG) 97-13. Int J Radiat Oncol Biol Phys. 2000;48(5):1307-10.

17. Richardson J, Smith JE, Mclntyre M, Thomas R, Pilkington $\mathrm{K}$. Aloe vera for preventing radiation-induced skin reactions: a systematic literature review. Clin Oncol. 2005;17(6):478-84.

18. Ryan JL. Ionizing radiation: the good, the bad, and the ugly. J Investig Dermatol. 2012;132(3 Pt 2):985-93.

19. Sachs RK, Brenner DJ. Solid tumor risks after high doses of ionizing radiation. Proc Natl Acad Sci U S A. 2005;102(37):13040-5.

20. Barnett GC, Wilkinson JS, Moody AM, Wilson CB, Twyman N, Wishart GC, et al. Randomized controlled trial of forward-planned intensity modulated radiotherapy for early breast cancer: interim results at 2 years. Int J Radiat Oncol Biol Phys. 2012;82(2):715-23.

21. McQuestion M. Radiation induced skin reactions. In: Haas MA, Moore-Higgs GJ, editors. Principles of skin care and the oncology patient. Pittsburg, PA: Oncology Nursing Society; 2010. p. 115-35.

22. Noble-Adams R. Radiation-induced reactions. 1: an examination of the phenomenon. Br J Nurs. 1999;8(17):1134-40.

23. Harris R, Probst $H$, Beardmore $C$, James $S$, Dumbleton C, Bolderston A, et al. Radiotherapy skin care: a survey of practice in the UK. Radiography. 2012;18(1):21-7. 
24. Gosselin TK, Schneider SM, Plambeck MA, Rowe K. A prospective randomized, placebo-controlled skin care study in women diagnosed with breast cancer undergoing radiation therapy. Oncol Nurs Forum. 2010;37(5):619-25.

25. Bennett C. An investigation into the use of a non-metallic deodorant during radiotherapy treatment: a randomised controlled trial. J Radiother Pract. 2009;8(1):3-9.

26. Watson LC, Gies D, Thompson E, Thomas B. Randomized control trial: evaluating aluminum-based antiperspirant use, axilla skin toxicity, and reported quality of life in women receiving external beam radiotherapy for treatment of stage 0,1 , and II breast cancer. Int J Radiat Oncol Biol Phys. 2012;83(1):e29-34.

27. Wong R, Bensadoun RJ, Boers-Doets C, Bryce J, Chan A, Epstein J, et al. Clinical practice guidelines for the prevention and treatment of acute and late radiation reactions from the MASCC Skin Toxicity Study Group. Support Care Cancer. 2013;21(10):2933-48.

28. Lewis L, Carson S, Bydder S, Athifa M, Williams AM, Bremner A. Evaluating the effects of aluminum-containing and non-aluminum-containing deodorants on axillary skin toxicity during radiation therapy for breast cancer: a 3-armed, randomized controlled trial. Int J Radiat Oncol Biol Phys. 2014;90(4):765-71.

29. Komarnicki J. Calgary study finds cancer patients able to use deodorant during therapy [Internet]. The Calgary Herald; 2010 [cited 2018 Sep 15]. Available from: http://www.calgaryherald.com/health/Calgary+study +finds+cancer+patients+able+deodorant+during+ therapy/3799636/story.html.

30. Bolderston A, Lloyd NS, Wong RKS, Holden L, RobbBlenderman L, members of the Supportive Care Guidelines Group. The prevention and management of acute skin reactions related to radiation therapy [Internet]. Cancer Care Ontario; 2005 [cited 2018 Sep 5]. Available from: https://www.cancercareontario.ca/ en/guidelines-advice/types-of-cancer/846.

31. Nystedt KE, Hill JE, Mitchell AM, Goodwin F, Rowe LA, Wong FL, et al. The standardization of radiation sk $k$ in care in British Columbia: a collaborative approach. Oncol Nurs Forum. 2005;32(6):1199-205.

32. Westbury C, Hines F, Hawkes E, Ashley S, Brada M. Advice on hair and scalp care during cranial radiotherapy: a prospective randomized trial. Radiother Oncol. 2000;54(2):109-16.

33. Campbell IR, Illingworth $\mathrm{MH}$. Can patients wash during radiotherapy to the breast or chest wall? A randomized controlled trial. Clin Oncol (R Coll Radiol). 1992;4(2):78-82.

34. Roy I, Fortin A, Larochelle M. The impact of skin washing with water and soap during breast irradiation:_a randomized study. Radiother Oncol. 2001;58(3):333-9.

35. Bolderston A, Lloyd NS, Wong RK, Holden L, RobbBlenderman L; Supportive Care Guidelines Group of Cancer Care Ontario Program in Evidence-Based Care. The prevention and management of acute skin reactions related to radiation therapy: a systematic review and practice guideline. Support Care Cancer. 2006;14(8):802-17.

36. Aistars J, Vehlow K. A pilot study to evaluate the validity of skin care protocols followed by women with breast cancer receiving external radiation. Int $\mathrm{J}$ Radiat Oncol Biol Phys. 2007;69(3 Suppl):S588-9.

37. Butcher K, Williamson K. Mananagement of erythema and skin preservation; advice for patients receiving radical radiotherapy to the breast: a systematic literature review. J Radiother Pract. 2012;11(1):44-54.

38. Harris R. Guidelines for grade III radiotherapy skin reactions. Prague: ESTRO; 2002.

39. Westbury C, Hines F, Hawkes E, Ashley S, Brada M. Advice on hair and scalp care during cranial radiotherapy: a prospective randomized trial. Radiother Oncol. 2000;54(2):109-16.

40. Harris R. Skin care in radiation therapy. New Orleans: ASRT; 2002.

41. Kedge EM. A systematic review to investigate the effectiveness and acceptability of interventions for moist desquamation in radiotherapy patients. Radiography. 2009;15(3):247-57.

42. Aistars $\mathrm{J}$. The validity of skin care protocols followed by women with breast cancer receiving external radiation. Clin J Oncol Nurs. 2006;10(4):487-92.

43. Society and College of radiographers (SCoR). Radiotherapy skin care guidelines. London: Society and College of radiographers; 2011.

44. McQuestion M. Evidence based skin care management in radiation therapy: clinical update. Semin Oncol Nurs. 2011;27(2):e1-17.

45. Haddad P, Amouzgar-Hashemi F, Samsami S, Chinichian S, Oghabian MA. Aloe vera for prevention of radiation-induced dermatitis: a self-controlled clinical trial. Curr Oncol. 2013;20(4):e345-8.

46. Olsen DL, Raub W Jr, Bradley C, Johnson M, Macias $\mathrm{JL}$, Love V, et al. The effect of aloe vera gel/mild soap versus mild soap alone in preventing skin reactions in patients undergoing radiation therapy. Oncol Nurs Forum. 2001;28(3):543-7.

47. Baney T, McQuestion M, Bell K, Bruck S, Feight D, Weis-Smith L, et al. Radiodermatitis. In: Erwin M, editor. Putting evidence into practice: improving oncology patient outcomes. Pittsburgh, PA: Oncology Nursing Society; 2011. p. 49-76.

48. Feight D, Baney T, Bruce S, McQuestion M. Putting evidence into practice. Clin J Oncol Nurs. 2011;15(5):481-92.

49. Liguori V, Guillemin C, Pesce GF, Mirimanoff RO, Bernier J. Double-blind randomized clinical trial comparing hyaluronic acid cream to placebo in patients treated with radiotherapy. Radiother Oncol. 1997;42(2):155-61.

50. Foschi D, Castoldi L, Radaelli E, Abelli P, Calderini G, Rastrelli A, et al. Hyaluronic acid prevents oxygen free-radical damage to granulation tissue: a study in rats. Int J Tissue React. 1990;12(6):333-9.

51. Leonardi MC, Gariboldi S, Ivaldi GB, et al. A doubleblind, randomized, vehicle-controlled clinical study to evaluate the efficacy of MAS065D in limiting the ef- 
fects of radiation on the skin: interim analysis. Eur $\mathrm{J}$ Dermatol 2008;18:317-321.

52. Primavera G, Carrera M, Berardesca E, et al. A doubleblind, vehicle-controlled clinical study to evaluate the efficacy of MAS065D formulation, in the management of radiationinduced dermatitis. Cutan Ocul Toxicol 2006;25:165-171.

53. Miltenburger HG, Baschong W, Horner V, Marx G. Cooperative effects in vitro on fibroblast and keratinocyte functions related to wound healing by transforming growth factor-beta and a low molecular weight fraction from hemolyzed blood. Arzneimittelforschung 1994;44:872-6.

54. Spessotto P, Dri P, Baschong W. Effect of a proteinfree dialysate from calf blood on human monocyte differentiation in vitro. Arzneimittelforschung/Drug Research 1993;747-51.

55. Sitton, E. 1992. Early and late radiation-induced skin alterations. Part II: Nursing care of irradiated skin. Oncol Nurs Forum, 19: 907-12.

56. Dunne-Daly, C. 1995. Skin and wound care in radiation oncology. Cancer Nursing, 18: 144-162.

57. Sperduti, A., Cashell, A., Rocca, C., Hirji, A. and Billingsley, S. 2006. A feasibility study of an internal control methodology using hydrocortisone cream for the management of skin reactions in patients receiving radical radiation therapy for cancers of the head and neck. Journal of Radiotherapy in Practice, 5: 211-218.

58. Bostrom, A., Lindman, H., Swartling, C., Berne, B. and Bergh, J. 2001. Potent corticosteroid cream (mometasone furoate) significantly reduces acute radiation dermatitis: results from a double-blind, randomized study. Radiotherapy and Oncology, 59: 257-265.

59. Miller RC, Schwartz DJ, Sloan JA, Griffin PC, Deming $\mathrm{RL}$, Anders JC, et al. Mometasone furoate effect on acute skin toxicity in breast cancer patients receiving radiotherapy: a phase III double-blind, randomized trial from the North Central Cancer Treatment Group N06C4. Int J Radiat Oncol Biol Phys. 2011;79(5):1460-6.

60. El Madani HA, Tancrède-Bohin E, Bensussan A, Colonna A, Dupuy A, Bagot $M$, et al. In vivo multiphoton imaging of human skin: assessment of topical corticosteroid-induced epidermis atrophy and depigmentation. J Biomed Opt. 2012;17(2):026009.

61. Hindley A, Dunn K. Mometasone furoate significantly reduces radiation dermatitis in patients undergoing breast radiotherapy: a double-blind randomized control trial in 120 patients. Atlanta: ASTRO, USA; Nottingham: UKRO, UK. Oral Scientific Sessions. 2013; 87(2S Suppl):S115.

62. Schmuth M, Wimmer MA, Hofer S, Sztankay A, Weinlich G, Linder DM, et al. Topical corticosteroid therapy for acute radiation dermatitis: a prospective randomized, double-blind study. Br J Dermatol. 2002;146(6):983-91.

63. Wells M, Macmillan M, Raab G, MacBride S, Bell N, MacKinnon K, et al. Does aqueous or sucralfate cream affect the severity of erythematous radiation skin reactions? A randomised controlled trial. Radiother Oncol. 2004;73(2):153-62.

64. Graham P, Browne L, Capp A, Fox C, Graham J, Hollis $J$, et al. Randomized paired comparison of No-Sting barrier film versus sorbolene cream (10\% glycerine) skin care during postmastectomy irradiation. Int J Radiat Oncol Biol Phys. 2004;58(1):241-6.

65. Spann CT, Tutrone WD, Weinberg JM, Scheinfeld N, Ross B. Topical antibacterial agents for wound care: a primer. Dermatol Surg. 2003;29(6):620-6.

66. Shell JA, Stanutz F, Grimm J. Comparison of moisture vapor permeable (MVP) dressings to conventional dressings for the management of radiation skin reactions. Oncol Nurs Forum. 1986;13(1):11-6.

67. Vuong T, Franco E, Lehnert S, Lambert C, Portelance L, Nasr E, et al. Silver leaf nylon dressing to prevent radiation dermatitis in patients undergoing chemothererapy and external beam radiotherapy to the perineum. Int J Radiat Oncol Biol Phys. 2004;59(3):809-14.

68. Tsang M, Guy RH. Effect of Aqueous Cream BP on

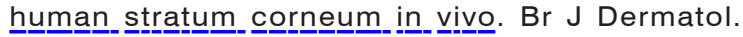
2010;163(5):954-8.

69. Patel AN, Varma S, Batchelor JM, Lawton PA. Why aque induced skin reactions. Clin Oncol ( $R$ Coll Radiol). 2013;25(4):272.

70. Campbell J, Lane C. Developing a skin-care protocol in radiotherapy. Prof Nurse. 1996;12(2):105-8.

71. Korinko A, Yurick A. Maintaining skin integrity during radiation therapy. Am J Nurs. 1997;97(2):40-4.

72. Tešanović D. Radijacioni dermatitis - izazov u savremenoj radioterapiji i uticaj na kvalitet života pacijentkinja sa karcinomom dojke [rad iz uže specijalizacije]. Novi Sad: Medicinski fakultet; 2018.

\section{Radiodermatitis - pregled mogućnosti lečenja}

\section{Sažetak}

Radijacioni dermatitis predstavlja jedan od najčešćih neželjenih efekata jonizujućeg zračenja koje se primenjuje u radioterapiji karcinoma svih lokalizacija, a najčešće kod tumora dojke, regije glave i vrata, pluća i sarkoma mekih tkiva. Najčešće se javlja kao komplikacija radioterapije dojke, te se stoga češće i registruje kod pacijenata ženskog pola na koži u regiji dojke koja se zra- či. Klinička slika radijacionog dermatitisa se može podeliti na 4 faze: akutna (eritem, suva deskvamacija, vlažna deskvamacija, ulceracija i nekroza sa posledičnom reepitelizacijom, rezidualna postinflamatorna hiperpigmentacija, redukcija i supresija sebacealnih i znojnih žlezda i epilacija); subakutna (hiperpigmentacije i hipopigmentacije, telangiektazije, atrofija kože, a moguće su i ulce- 
racije), hronična (atrofija kože, dermalne fibroze i trajna epilacija kože) i kasna faza (povečan rizik za pojavu kancera kože). Radi prevencije radijacionog dermatitisa važno je da se tokom radioterapije upotrebljavaju proizvoda za negu kože koji će smanjiti ili zaustaviti učestalost kožnih reakcija i poboljšati kvalitet života. lako se u terapiji osim topijskih kortikosteroida preporučuju brojni proizvodi sa aktivnim sastojcima kao što su npr. aloja vera, kalendula, hijaluronska kiselina, sukralfat, sorbolen, mineralna i maslinova ulja, med, vitamin C, cink, antimikrobna sredstva i srebro, nije postignut zajednički terapijski konsenzus o njihovoj upotrebi kod radijacionog dermatitisa. Iz tog razloga tretman treba da bude vođen osnovnim smernicama, a prilagođen individualnim potrebama svakog pojedinog pacijenta.

Ključne reči: Radiodermatitis; Znaci i simptomi; Radijacione povrede; Zaštita od radijacije; Nega kože; Dezodoransi; Kreme za kožu; Antimikrobna sredstva

Received 26 July, 2018

Accepted 15 September, 2018 